\title{
Molecular cloning and sequencing analysis of the interferon $\beta$ from Coturnix
}

\author{
BEI ZHENG, WEI-SHAN CHANG
}

Shandong Agriculture University, Taian, PR China

\begin{abstract}
One pair of primers was designed according to Gallus and Meleagris gallopavo interferon $\beta(I F N-\beta)$ sequences published in GenBank. The primers and RNA extraction from the spleen of Coturnix were used to amplify Coturnix IFN- $\beta$ cDNA by real-time polymerase chain reaction (RT-PCR). The product was cloned into pEasy-T1 vector. Evaluating recombinant plasmid by PCR and restriction enzyme digestion. Sequence the cloning sequences, comparing the sequencing results by NCBI. We successfully got a Coturnix IFN- $\beta$ partial sequence. The sequence was subtyped and put to homologous analysis. The results suggested the homology of IFN- $\beta$ gene of Coturnix and chicken (88.7\%), the homology of IFN- $\beta$ gene of Coturnix and Anas platyrhynchos (72.5\%), the homology of IFN- $\beta$ sequence registered in GenBank. The analysis of the genetic tree showed that the relationship of Coturnix and chicken IFN- $\beta$ had a high homology. It can be seen that in this study we successfully got a partial sequence of IFN- $\beta$ of quail.
\end{abstract}

Key words: coturnix, IFN- $\beta$, gene cloning, gene sequence analysis.

(Centr Eur J Immunol 2014; 39 (1): 25-29)

\section{Introduction}

The immune response against viral pathogens includes specific and non specific mechanisms. Cytokines are peptides which can play a role in the non specific immunity [1]. Interferon (IFN) is a kind of highly active multifunctional glycoprotein, and it is an important cytokine with a broad range of biological activities [2]. Interferon is a secretory glycoprotein produced by the biological cells when it is subjected to the influence of the virus or other inducing agent [3]. Interferon has many kinds of bioactivity, such as antiviral activity, immune regulation and so on [4]. Interferon is an important part of the body's defense system. Interferon has broad-spectrum resistance [5]. When interferon acts on the body's organic tissue cells, it can make it obtain the ability to resist a variety of viruses and microbes [6]. Interferon has strict selectivity for a somatic cell, and has a relative species specificity. But the specificity is relative, not absolute [7]. Interferon can be divided into type I and type II [8]. Interferon of type I is a product of many gene families, including 14-20 interferon $\alpha$ genes, 1 kind of interferon $\beta$ gene; interferon of type $\alpha$ contains only one family member, namely the interferon $\gamma$ [9]. Type I interferons are the most effective antiviral cytokines. Type I interferon genes are located on chromosome 9 , and are segregated in a "modern" and an "ancestral" group with distinctive effects on the cells. Interferons $\alpha$ are represented by a large family of structurally related genes while the IFN- $\beta$ is encoded by a single gene $[1,10,11]$.

The meat and eggs of Coturnix were delicious in China and known as "animal's ginseng". Currently, the number of Coturnix raised is about 200 million in China, which is $1 / 5$ of the world production. Coturnix is an important part of the economic animal production in China. But the occurrence of avian influenza and New-castle diseases posed a serious threat to the production of Coturnix. Establishing the Coturnix immune mechanism, looking for a new and efficient security immune route makes it necessary to breed Coturnix. By contrast, the research on animal interferon lags behind. There/This is still the main stay/subject? in basic research and clinical trials, and most concentrating on a few animals such as pigs, chicken, fish. But a big progress has been made in recent years. There are commercial interferon of pigs, dogs, chicken and recombinant interferon product coming to the market. However, there are very few research reports about the Coturnix interferon.

\section{Material and methods}

\section{Sample}

Spleen was collected from Coturnix. Coturnix was brought as a live mature Coturnix from a common farm and kept under inspection for 5 days to be sure that it is

Correspondence: Bei Zheng, Shandong Province, Taian, Daizong Street No.61, 271000 Taian, PR China, e-mail: 302981954@qq.com 
free from any clinical infection, then the sample was collected and stored at $-20^{\circ} \mathrm{C}$.

\section{Primer design}

We downloaded the complete IFN- $\beta$ mRNA sequences of the Gallus (NM_001024836) and Meleagris gallopavo (U28140) from GenBank. The sequence was aligned using the ClustalW application (Dnastar software) where we designed primers match with the alignment of the sequences.

\section{Amplification of cDNA sequence}

Total RNA from Coturnix spleen was extracted by Trizol (TransGen) according to the manufacturer's protocol and was reverse transcribed to cDNA. Reverse transcription is processed with a Prime script real-time (RT) reagent kit (TaKaRa) according to the manufacturer's instructions in $10 \mu \mathrm{l}$ reaction system. The reagent was blended and put in the polymerase chain reaction (PCR) Amplifier at $37^{\circ} \mathrm{C}$ for $15 \mathrm{~min}$ and inactivated at $85^{\circ} \mathrm{C}$ for $5 \mathrm{~s}$.

The PCR using the reverse transcription product was performed to amplify the target gene using specific primers. Polymerase chain reaction mixtures contained $50 \mathrm{pmol}$ for each forward and reverse primer, $1 \mu \mathrm{l}$ template cDNA, $200 \mu \mathrm{M}$ dNTP mix and $0.2 \mu \mathrm{l} 5 \mathrm{U}$ Ex Taq polymerase (TransGen) in $1 \times$ Ex buffer up to $25 \mu \mathrm{l}$ with $\mathrm{ddH}_{2} \mathrm{O}$. The PCR was processed in the PCR Amplifier as follows: initial denaturation at $94^{\circ} \mathrm{C}$ for $5 \mathrm{~min}, 35$ cycles at $94^{\circ} \mathrm{C}$ for $30 \mathrm{~s}$, annealing at $55^{\circ} \mathrm{C}$ for $30 \mathrm{~s}$, extension at $72^{\circ} \mathrm{C}$ for

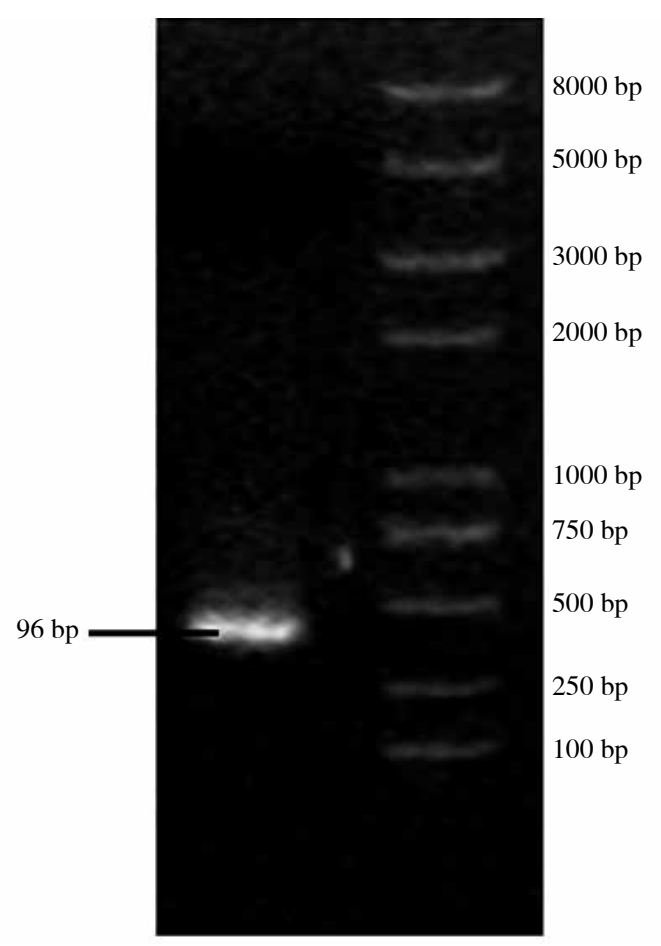

Fig. 1. Real-time PCR amplification of interferon $\beta$
$30 \mathrm{~s}$, final extension at $72^{\circ} \mathrm{C}$ for $10 \mathrm{~min}$. The PCR amplicons were verified by $0.8 \%$ agarose gel electrophoresis at $120 \mathrm{~mA}$ for $30 \mathrm{~min}$ and products were visualized by staining with DuRed (Fanbo Biochemicals), we checked the band and got the images with GelDoc ${ }^{\mathrm{TM}} \mathrm{XR}+$ system (Bio-RAD, USA).

\section{Construction and identification of recombinant plasmid with interferon $\beta$}

The Gel Extraction Kit was used to purify and recycle the PCR products. With reference to the instruction of cloning vector pEasy $-\mathrm{T} 1$, in order to join the components in the $10 \mu \mathrm{l}$ reaction system, the following steps were taken. After gently blending, we put it in the PCR instrument to connect $25^{\circ} \mathrm{C} 10 \mathrm{~min}$ for conversion. Getting $5 \mu$ l connecting product into fresh preparative DH5a cells, coating converted products on the $\mathrm{LB} / \mathrm{Amp}$ plate evenly under aseptic conditions. Putting the tablet at $37^{\circ} \mathrm{C}$ thermostat in $12 \mathrm{~h}$ and picking a single colony after culturing, preparing and evaluating plasmid DNA. Picking a single colony from the above overnight culture tablet randomly, vaccinating in $5 \mathrm{ml} \mathrm{LB}$ liquid medium containing Amp. Shaking culture overnight in $37^{\circ} \mathrm{C}$, preparing plasmid DNA using GenEluteTM High Performance Plasmid Kits. Evaluating recombinant plasmid by PCR and restriction enzyme digestion. In order to further determine the resulting clone, recombinant plasmid identified as positive clones after the above steps was sent to Shanghai Sangon Biological Company for DNA sequencing. Sequencing results and the nucleotide sequence registered in GenBank was subtyped and put to homologous analysis.

\section{Interferon- $\beta$ nucleotide sequence homology comparison and the analysis of the phylogenetic tree}

The sequence of the Coturnix IFN- $\beta$ mRNA was blast in the GenBank using nucleotide blast and the translated amino acids were also blast by protein blast to check whether the new sequence is related to any other cloned gene.

The sequence of Coturnix IFN- $\beta$ was compared with the known IFN- $\beta$ mRNA sequences from different species which were downloaded from the GenBank and aligned by Dnastar software. Sequencing results of Coturnix IFN- $\beta$ and the nucleotide sequence of Gallus (NM_001024836), Meleagris gallopavo (U28140), A. platyrhynchos (X84764), Mus musculus (NM_010510), Callithrix jacchus (AB571244), Ovis aries (NM_001009392), Danio rerio (NM_001261449), Papio anubis (NM_001173536), Macaca mulatta (NM_001042733), Homo sapiens (NM_000600), Mus musculus (NM_010510), Canis lupus familiaris (NM_001135787), Sus scrofa (NM_001003923), Oryctolagus cuniculus (NM_001082064) registered in GenBank was subtyped and put to homologous analysis. The phylogenetic tree was constructed from the gene alignments and the amino acid alignments. 


\section{Results}

\section{Interferon gene cloning results}

Total RNA was extracted from Coturnix spleen cells, then amplified to products by RT-PCR. The PCR products underwent electrophoresis in $0.8 \%$ agarose gel. There was a specific band in 400 bp with expectations (Fig. 1).

\section{Interferon $\beta$ sequence analysis}

The partial mRNA sequence of Coturnix IFN- $\beta$ consists of 396 nucleotides. The homology of IFN- $\beta$ gene of Coturnix and Gallus was $88.7 \%$. The consensus cDNA sequence showed $72.5 \%$ identity with A. platyrhynchos and $71.5 \%$ identity with Meleagris gallopavo as compared with the nucleotide sequence registered in GenBank (Figs. 2, 3). The

\begin{tabular}{|c|c|c|c|c|c|c|c|c|c|c|c|c|c|c|c|}
\hline & 1 & 2 & 3 & 4 & 5 & 6 & 7 & 8 & 9 & 10 & 11 & 12 & 13 & & \\
\hline 1 & & 93.1 & 34.0 & 33.6 & 33.0 & 33.9 & 31.3 & 92.8 & 33.7 & 64.9 & 93.7 & 36.3 & 38.0 & 1 & Callithrix jacchus seq. \\
\hline 2 & 7.3 & & 34.6 & 34.8 & 34.9 & 34.8 & 32.2 & 99.2 & 35.5 & 64.1 & 97.5 & 36.3 & 38.0 & 2 & Macaca mulatta seq. \\
\hline 3 & 165.3 & 158.6 & & 70.8 & 43.8 & 44.6 & 62.1 & 34.6 & 35.7 & 35.5 & 35.5 & 44.0 & 45.4 & 3 & Ovis aries seq. \\
\hline 4 & 171.5 & 157.6 & 37.6 & & 41.4 & 43.8 & 64.8 & 34.9 & 37.7 & 34.2 & 35.7 & 43.3 & 43.4 & 4 & Canis lupus familiaris seq. \\
\hline 5 & 168.3 & 151.9 & 103.9 & 114.3 & & 41.4 & 38.2 & 34.9 & 29.7 & 29.9 & 30.1 & 67.0 & 72.5 & 5 & A. platyrhynchos IFN gene seq. \\
\hline 6 & 165.3 & 156.5 & 100.9 & 103.7 & 34.3 & & 41.7 & 34.6 & 34.9 & 36.5 & 34.8 & 72.0 & 71.5 & 6 & Meleagris gallopavo interferon, partial \\
\hline 7 & 203.4 & 186.2 & 54.4 & 49.1 & 130.5 & 113.9 & & 32.2 & 34.0 & 33.3 & 31.7 & 41.7 & 43.9 & 7 & Mus muculus seq. \\
\hline 8 & 7.6 & 0.8 & 159.6 & 156.7 & 151.8 & 157.9 & 197.7 & & 35.5 & 64.1 & 97.7 & 36.3 & 38.0 & 8 & Papio anubis seq. \\
\hline 9 & 178.4 & 160.1 & 152.9 & 137.1 & 213.7 & 151.9 & 169.7 & 160.1 & & 35.6 & 33.8 & 33.4 & 35.2 & 9 & Danio rerio seq. \\
\hline 10 & 48.9 & 50.5 & 149.8 & 161.8 & 204.0 & 141.3 & 166.8 & 50.3 & 148.2 & & 66.9 & 35.0 & 35.1 & 10 & Oryctolagus cuniculus seq. \\
\hline 11 & 6.7 & 2.5 & 150.1 & 149.2 & 203.0 & 155.3 & 193.0 & 2.4 & 178.1 & 44.6 & & 36.6 & 38.3 & 11 & Homo sapiens seq. \\
\hline 12 & 149.9 & 152.7 & 103.1 & 106.4 & 43.8 & 35.4 & 113.8 & 151.0 & 168.3 & 154.8 & 148.1 & & 88.7 & 12 & Gallus seq. \\
\hline 13 & 133.4 & 134.6 & 97.5 & 105.5 & 34.6 & 36.2 & 103.8 & 134.2 & 150.2 & 150.2 & 132.0 & 12.5 & & 13 & Coturnix seq. \\
\hline & 1 & 2 & 3 & 4 & 5 & 6 & 7 & 8 & 9 & 10 & 11 & 12 & 13 & & \\
\hline
\end{tabular}

Fig. 2. Homology comparisons of nucleotide sequence among chickens, quails, ducks and other animals interferon $\beta$ from GenBank

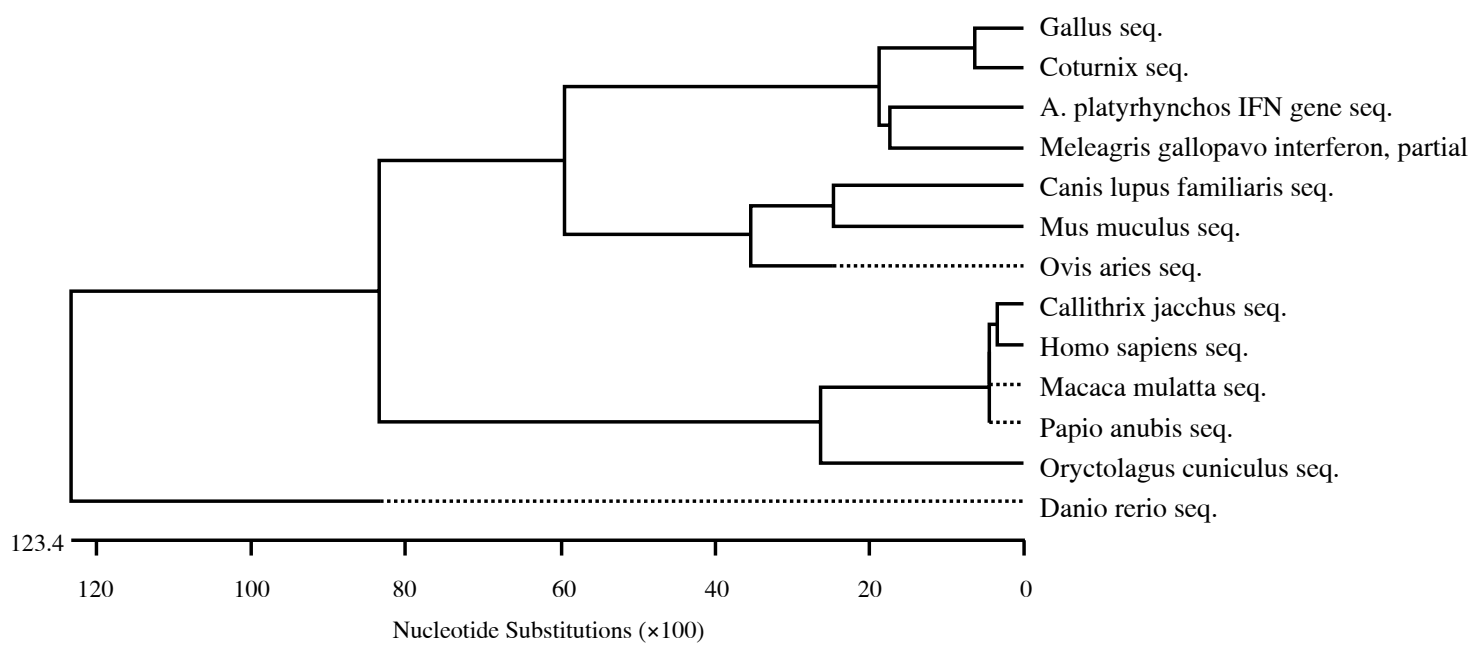

Fig. 3. The evolutionary tree of quail compared with other animals from GenBank 
analysis of the genetic tree confirmed that the new sequence is probably a homolog to gallus IFN- $\beta$ while the relationship of Coturnix and Gallus IFN- $\beta$ had high homology.

\section{Interferon $\beta$ amino acid sequence analysis}

The predicted protein encoded by Coturnix IFN- $\beta$ mRNA sequence is composed of 132 amino acids. The predicted amino acid sequence of Coturnix IFN- $\beta$ was compared with the IFN- $\beta$ of Gallus and Meleagris gallopavo using DNAMAN (Fig. 4). The homology of IFN- $\beta$ amino acid of Coturnix and Gallus was $78.8 \%$, the homology of IFN- $\beta$ amino acid of Coturnix and Meleagris gallopavo was $56.8 \%$ as compared with the amino acid sequence (Figs. 5, 6). The analysis of the phylogenetic tree
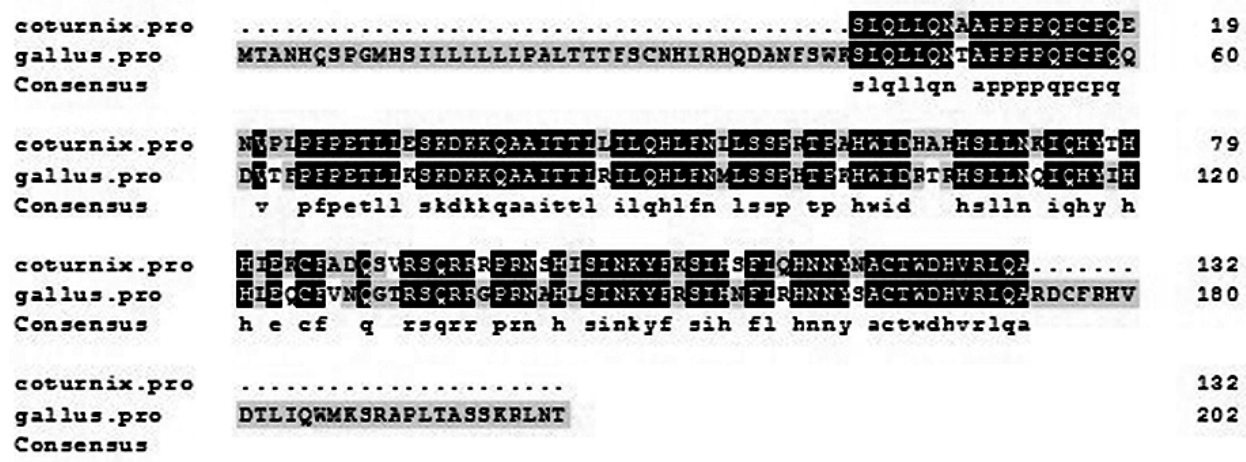

Fig. 4. Results of multiple alignments of amino acid sequences

\begin{tabular}{|c|c|c|c|c|c|c|c|c|c|c|c|}
\hline & 1 & 2 & 3 & 4 & 5 & 6 & 7 & 8 & 9 & & \multirow{3}{*}{$\begin{array}{l}\text { Papio anubis pro. } \\
\text { Canis lupus familiaris pro }\end{array}$} \\
\hline 1 & & 10.7 & 13.9 & 11.2 & 15.0 & 98.6 & 10.2 & 12.2 & 9.8 & 1 & \\
\hline 2 & 476.0 & & 20.7 & 62.6 & 9.8 & 10.7 & 49.7 & 19.6 & 19.1 & 2 & \\
\hline 3 & 357.0 & 238.0 & & 19.0 & 10.0 & 13.9 & 21.7 & 53.4 & 78.8 & 3 & \multirow{2}{*}{$\begin{array}{l}\text { Gallus pro. } \\
\text { Sus scrofa pro. }\end{array}$} \\
\hline 4 & 447.0 & 51.5 & 258.0 & & 10.4 & 11.2 & 62.0 & 17.4 & 19.8 & 4 & \\
\hline 5 & 328.0 & 524.0 & 517.0 & 493.0 & & 15.5 & 8.2 & 7.4 & 10.2 & 5 & \multirow{6}{*}{$\begin{array}{l}\text { Danio rerio pro. } \\
\text { Macaca mulatta pro. } \\
\text { Ovis aries pro. } \\
\text { Meleagris gallopavo pro. } \\
\text { Coturnix pro. }\end{array}$} \\
\hline 6 & 1.4 & 476.0 & 357.0 & 447.0 & 317.0 & & 10.2 & 12.2 & 9.8 & 6 & \\
\hline 7 & 504.0 & 80.6 & 226.0 & 52.5 & 688.0 & 504.0 & & 20.1 & 22.1 & 7 & \\
\hline 8 & 407.0 & 252.0 & 71.1 & 284.0 & 819.0 & 407.0 & 244.0 & & 56.8 & 8 & \\
\hline 9 & 524.0 & 258.0 & 25.0 & 248.0 & 504.0 & 524.0 & 221.0 & 63.3 & & 9 & \\
\hline & 1 & 2 & 3 & 4 & 5 & 6 & 7 & 8 & 9 & & \\
\hline
\end{tabular}

Fig. 5. Homology comparisons of amino acid sequence among Gallus, Coturnix, and Meleagris gallopavo

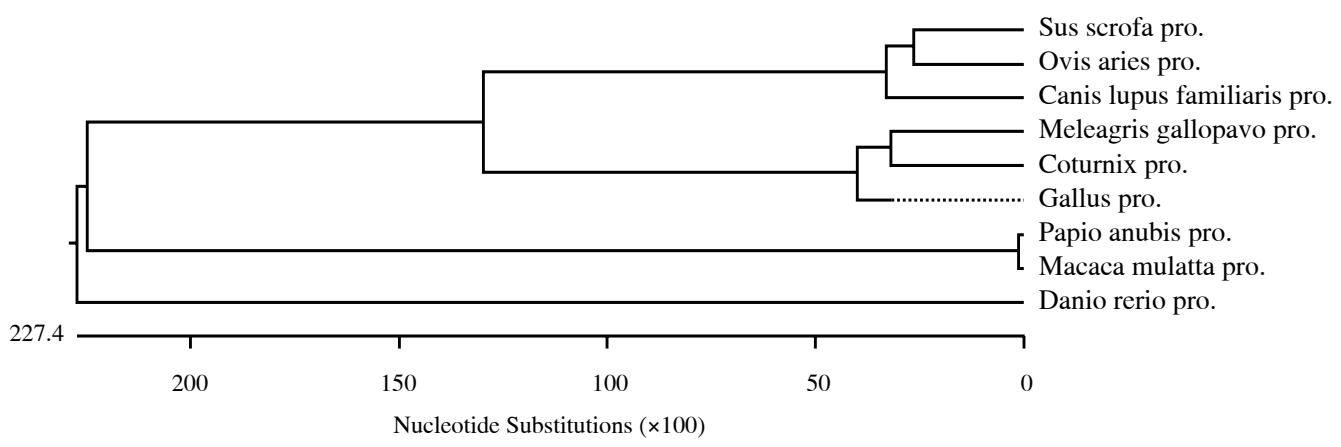

Fig. 6. The evolutionary tree of quail as compared with other animals 
showed that the relationship of Coturnix and Gallus IFN- $\beta$ had a high homology.

\section{Conclusions}

Temporarily quail $\beta$ interferon gene sequence is not published at home and abroad. This is the first study to focus on the sequence of Coturnix IFN- $\beta$. We successfully got a Coturnix INF- $\beta$ partial sequence. The sequence was subtyped and put to homologous analysis. Our results proved that the relationship of Coturnix and Gallus IFN- $\beta$ had a high homology.

The predicted protein encoded by Coturnix IFN- $\beta$ mRNA sequence has a high homology to Gallus. This may have a role in the difference of the immune response against pathogen between Coturnix and Gallus. The result can be a reference for further research and practical application.

Authors declare no conflict of interest.

\section{References}

1. Chieux V, Hober D, Chehadeh W, Wattr P (1999): Anti-viral proteins: from interferon alpha to its receptor. Ann Biol Clin 57: 283-290.

2. Le Bon A, Schiavoni G, D’Agostino G, et al. (2001): Type I interferons potently enhance humoral immunity and can promote isotype switching by stimulating dendritic cells in vivo. Immunity 14: 461-470.

3. Samuel CE (2001): Antiviral actions of interferons. Clin Microbiol Rev 14: 778-809.

4. Roberts RM, Liu L, Guo Q, et al. (1998): The evolution of the type I interferons. J Interferon Cytokine Res 18: 805-816.

5. Shtrichman R, Samuel CE (2001): The role of gamma interferon in antimicrobial immunity. Curr Opin Microbiol 4: 251259.

6. Imada K, Leonard WJ (2000): The Jak-STAT pathway. Mol Immunol 37: 1-11.

7. Ruvolo V, Navarro L, Sample CE, et al. (2003): The Epstein-Barr virus SM protein induces STATI and interferon stimulated gene expression. J Virol 77: 3690-3701.

8. Rodriguez JJ, Wang LF, Horvath CM (2003): Hendra virus V protein inhibits interferon signaling by preventing STATI and STAT2 nuclear accumulation. J Virol 77: 11842-11845.

9. Wen Z, Zhong Z, Darnell JE Jr (1995): Maximal activation of transcription by Stat 1 and Stat 3 requires both tyrosine and serine phosphorylation. Cell 82: 241-250.

10. Vinkemeier U, Moarefi I, Darnell JE Jr, Kuriyan J (1998): Structure of the amino-terminal protein interaction domain of STAT-4. Science 279: 1048-1052.

11. Takeda K, Kaisho T, Yoshida N, et al. (1998): Stat 3 activation is responsible for IL-6-dependent T-cell proliferation through preventing apoptosis: generation and characterization of T cell-specific Stat 3-deficient mice. J Immunol 161: 46524660. 